\title{
On the Quantity Analysis of Classroom Teaching Behavior between China and America: A Case Study
}

\author{
Bo ZHAO ${ }^{1}$ and Ying-juan PENG ${ }^{2}$ \\ ${ }^{1}$ School of Information Science and Technology, Yunnan Normal University, \\ Yunnan Kunming, China \\ ${ }^{2}$ Key Laboratory of Educational Informalization for Nationalities (Yunnan Normal \\ University), Ministry of Education
}

Keywords: FIAS, Classroom teaching behavior, Quantity analysis.

\begin{abstract}
China and America all pay high attention to classroom teaching. However, the persons they cultivate are different in both talent and abilities. What exact difference of classroom teaching behavior does there exist between China and America? So, in the paper, two lessons are chosen from Netease Website. One is American philosophy lesson and another is Chinese philosophy lesson. Furthermore, from multiply aspect at the microcosm level, we analyze quantitatively them by FIAS in order to clearly know essential difference of classroom teaching between China and America.
\end{abstract}

\section{Introduction}

China and America all pay high attention to education. In the international mathematical Olympiad, Chinese students were crowned champion 17 times from 1985 to 2012 while American students were only crowned champion 5 times from 1974 to 2012 . However, more than $70 \%$ of the world's Nobel prizes are American and no one is Chinese before 2012 according to statistics. So, Mr. Xuesheng Qian raised a question why our school cannot develop outstanding student. British scientist Joseph Needham in his work "Science and Civilization in China" also raised "why China had been overtaken by the West in science and technology, despite its earlier successes?". This is known as "The Needham Question". Gunpowder, magnetic compass, paper and printing, Francis Bacon considered as the three most important inventions which facilitate the West's transformation from the Dark Ages to the modern world, were invented in China. Science and technology in ancient China was once in the leading position in the world, but why do it fall behind in modern times[1].

The development of science and technology needs education's support. Classroom teaching, as an important part of school education, plays significant role in university education. However, the professional competence and innovation of students are influenced by quality of classroom teaching. Effect of classroom teaching is influenced by classroom teaching behavior of teacher. Many scholars research difference of classroom teaching behavior between China and America by observation and offer qualitative analysis. What exact difference in education does there exist between China and America? In the paper, at the microcosmlevel, we analyze quantitatively American philosophy lesson and Chinese philosophy lesson from Netease Website by FIAS in order to find difference in classroom teaching behavior between China and America.

The paper is organized as follows. Section 2 describes FIAS. Section 3 discusses difference in classroom teaching behavior between China and America through comparing 
American philosophy lesson and Chinese philosophy lesson from Netease Website by FIAS. Finally, conclusion can be found in section 4.

\section{The Introduction of FIAS Method}

Flanders' approach derives from the idea that teaching takes place in a series of repeated communication acts between teachers and students which tells us what interaction is taking place. These 'acts' could be described as particular features of behavior, relating to specific activities which can then be clearly observed and identified [2]. It is called Flanders' Interaction Analysis System, for short FIAS.

It consists of three parts: a set of code which describes the classroom interaction, namely scale; a set of standards which is the rule used for observing and recording code; a transfer matrix which is used for displaying data.

Classroom teaching behavior is divided into 10 categories in FIAS, as shown in table 1 from item 1 to item 10[3], where item 1 to item 7 is teacher's verbal to student; item 8 to item 9 is students' verbal to the teacher, item 10 expresses that classroom is quiet or confusion which may occur. With the development of education informatization, new media and new technologies emerge in classroom teaching and the categories of classroom teaching's 'act' in FIAS cannot meet analysis of classroom teaching. Two items are added to it, as shown in table 1 fromitem 11 to item 12, where item 11 expresses that students think under the guidance of the teacher or do homework in class and item 12 expresses teacher uses media to present the teaching content and knowledge.

Table 1. Categories of class room teaching behavior

\begin{tabular}{|c|c|l|}
\hline Classification & Code & \multicolumn{1}{|c|}{ Description } \\
\hline \multirow{4}{*}{ Teacher verbal } & 1 & accepts student's feelings, shows sympathy in constructive way \\
\cline { 2 - 3 } & 2 & praises, encourages, jokes, approves of what student is doing \\
\cline { 2 - 3 } & 3 & uses, accepts, clarifies and expands student's ideas \\
\cline { 2 - 3 } & 4 & asks questions (non-rhetorical), stimulates student \\
\cline { 2 - 3 } & 6 & explains, tells, gives lecture, introduces own opinion \\
\cline { 2 - 3 } & 7 & $\begin{array}{l}\text { gives directives or ins tructions, organizes } \\
\text { or actions }\end{array}$ \\
\hline \multirow{3}{*}{ Student verbal } & 8 & answers teacher, but after contact has been initiated \\
\cline { 2 - 3 } Silence & 9 & begins dialogue, is active, initiates contact \\
\cline { 2 - 3 } & 10 & students are silent or confused, communicates indistinctly \\
\hline \multirow{2}{*}{$\begin{array}{c}\text { Assist } \\
\text { teaching by } \\
\text { the media }\end{array}$} & 11 & students think under the guidance of the teacher or do homework in class \\
\hline
\end{tabular}

\section{Quantity Analysis of Classroom Teaching Behavior of China and America}

\section{Research Sample}

On November 1, 2010, Netease launches "the Video of GlobalFamous Public Class Project" in China. More than 1200 courses have been online. There are more than 200 courses with Chinese subtitles. The user could be free online watching the video of public class on Netease, which are from world-class university (for example Harvard University) as well as domestic 
famous university (for example Tsinghua University and Peking University). FromNetease, we selected two philosophy lessons as case study. A class with 24 minutes is from Harvard University and a class with 37 minutes is from Chinese famous university.

Table 2. Percentage of classroom teaching behavior

\begin{tabular}{|c|c|c|c|c|c|c|c|c|c|c|c|c|c|}
\hline & & $\begin{array}{c}\text { Item } \\
1\end{array}$ & $\begin{array}{c}\text { Item } \\
2\end{array}$ & $\begin{array}{c}\text { Item } \\
3\end{array}$ & $\begin{array}{c}\text { Item } \\
4\end{array}$ & $\begin{array}{c}\text { Item } \\
5\end{array}$ & $\begin{array}{c}\text { Item } \\
6\end{array}$ & $\begin{array}{c}\text { item } \\
7 \\
\end{array}$ & $\begin{array}{c}\text { Item } \\
8\end{array}$ & $\begin{array}{c}\text { Item } \\
9\end{array}$ & $\begin{array}{c}\text { Item } \\
10\end{array}$ & $\begin{array}{c}\text { Item } \\
11 \\
\end{array}$ & $\begin{array}{c}\text { Item } \\
12 \\
\end{array}$ \\
\hline \multirow{2}{*}{ China } & Number & 0 & 0 & 0 & 30 & 630 & 0 & 0 & 0 & 0 & 0 & 0 & 64 \\
\hline & Percentage & 0 & 0 & 0 & 4.14 & 87.02 & 0 & 0 & 0 & 0 & 0 & 0 & 8.84 \\
\hline \multirow{2}{*}{ American } & Number & 11 & 5 & 8 & 61 & 291 & 4 & 0 & 41 & 33 & 10 & 0 & 8 \\
\hline & Percentage & 2.33 & 1.06 & 1.69 & 12.9 & 61.6 & 0.85 & 0 & 8.69 & 6.99 & 2.12 & 0 & 1.69 \\
\hline
\end{tabular}

\section{Research Result}

We applied the FIAS method to two philosophy lessons and recorded respectively activity features of classroom teaching behavior at intervals of 3 seconds (every three seconds) and encoded them according to table 1. According analysis matrix in FIAS, we have summarized the number and percentage of total indicators from item 1 to item 12 in FIAS, as shown in table 2. According to table 2, classroom teaching behavior of China and America are analyzed as follows.

(1)The effectiveness of asking questions: In Chinese philosophy lesson, the number of teacher's asking question(item 4 ) is 30 and its percentage is $4.14 \%$ while the percentage of students' verbal (item 8 and item 9) is zero, which suggests that in Chinese philosophy lesson, teacher asked a lot of question. However, students did not answer them and teacher also did not give time to let students think or inspire students to think. Classroom teaching is teacher-centred. However, in American philosophy lesson, the number of teacher's asking question(item 4) is 61 and its percentage is $12.9 \%$ while the percentage of students' verbal (item 8 and item 9) is $15.68 \%$, which suggests that student could think and answer the question in class. Teaching video also shows that the teacher usually asks open-ended question instead of focusing on recall and management questions. The teacher of America could encourage student to think, arouse student's interest and curiosity, develop students' reflection and stimulate students to ask questions after he ask the question.

From two teaching video, we can also know that Chinese teacher only presents question without to inspire students thinking fully. American teacher not only presents many questions but also inspires student thinking from many perspective and the questionings are effective. So, classroom teaching is teacher-centred in China but is student-centred in America. Moving from teacher-centered teaching to student-centered teaching implies a perspective of the approaches to questioning [4].

(2)Teacher-student interaction: Bartholomew (2009) asserted that positive teacher-student interaction can encourage students' attendance in class[5]. However, in Chinese philosophy lesson, the number of students' verbal (item 8 and item 9) is zero which

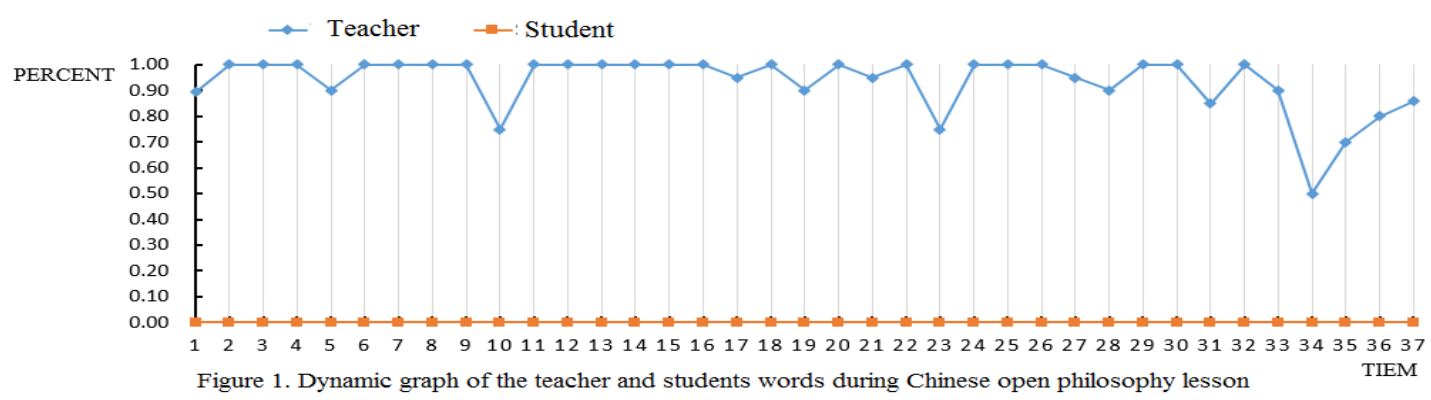


suggests that there is not any interaction between teacher and student. But in American philosophy lesson, the number of students' verbal (item 8 and item 9) is 74 and its percentage

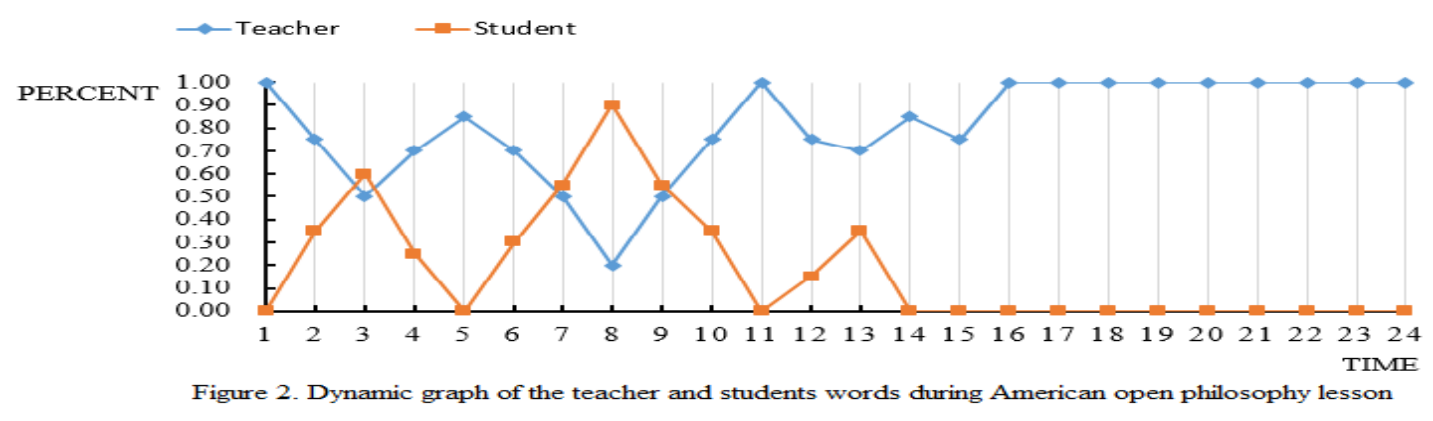

is $15.68 \%$, which suggests that communication and interaction between teacher and student are warmly.

At the same time, we present interaction between teacher and students visually, such as figure 1 and figure 2. Figure 1 is dynamic graph of the teacher and students words during Chinese open philosophy lesson and figure 2 is dynamic graph of the teacher and students words during American open philosophy lesson. In figure 1 and figure 2, the $\mathrm{X}$-axis stands for time to measure and time is shown in minute. Y-axis stands for the verbal percentage of teacher and students respectively per minute. There is no interaction between teacher and students and the students are in listening teacher in Chinese philosophy lesson, as figure 1 shown. There are many interactions between teacher and students and more students participated in answering in American philosophy lesson, as figure 2 shown. That is, more students think and speculate under the teacher enlighten.

(3)Waiting time: item 11 of table 2 has shown that whether Chinese teacher or American teacher did not provide enough wait-time to student for thinking after asking a question. However, the wait-time is essential to student thinking. In Rowe investigations, he(1986) found that if teacher provides wait time with three to five seconds, the quantity and quality of students' answer are improved significantly: students give longer responses, students give more evidence for their ideas and conclusions, students can speculate and hypothesize. More and more students participate in responding. Furthermore, students ask more questions and talk more to other students [6].

(4)The teacher's attitude toward students in the classroom: The teacher's attitude toward student in the classroom is measured in item 1 , item 2 , item 3 and item 7 of Table 2 . Teacher's attitude toward students, as a nonverbal communication in the classroom, is a way of enhancing classroom teaching and is powerful tools for both lesson delivery and for class management [7]. However, in Chinese philosophy lesson, the number of item 1, item 2, item 3 and item 7 are all zero. It suggests that teacher did not pay attention to behavior or actions of students even if teacher has asked a lot of questions (as shown on item 4 of Table 2). The teacher more focused on delivery knowledge and neglected response and feedback from the students. It is disadvantage to arouse student's learning interest. In America philosophy lesson, the number of item 1 is 11 and its percentage is $2.33 \%$ which shows teacher can focus on students' questions and solve students' questions in constructive way. The number of item 2 is 5 and its percentage is $1.06 \%$ which shows teacher can praise and encourage students to think. Classroom atmosphere is actively.

Item 7 is zero whether in Chinese philosophy lesson or in American philosophy lesson which shows two teachers did not criticize and enforce to change student's unsuitable behavior or 
actions. But in American philosophy lesson, teacher putted the focus on student's behavior and tried to guide student in constructive way (as shown on item 1 of Table 2).

(5)Using media: In Chinese philosophy lesson, the number of using media to present the teaching content (item 12) is 64 and its percentage is $6.64 \%$. On the other hand, the number of teacher's lecture (item 5) is 630 and its percentage is $87.3 \%$ while the number of students' verbal (item 8 and item 9 ) is zero. It suggests that the classroom teaching is a one-way activity and the teacher's lecture is done through a lot of multimedia courseware. Teacher and student did not interact with each other in class, which confirmed by teaching video.

In America philosophy lesson, the number of using media to present the teaching content (item 12) is 8 and its percentage is $1.69 \%$. On the other hand, the number of teacher's lecture (item 5) is 291 and its percentage is $61.6 \%$ while the percentage of students' verbal (item 8 and item 9 ) is $15.68 \%$. From the teaching video, we also know that the teacher presents the case through multimedia and asks a lot of question. At the same time, the teacher also can stimulate students to think. The Students can actively participate in classroom teaching.

\section{Summary}

Classroom teaching is main way of education. It influences learning quality of student directly. From the above two teaching case, we can know that different classroom teaching behavior reflects the different teaching ideas of the teacher. So, we sum difference between China and America as below according to above discussion.

(1)Teacher idea: The difference of the classroom teaching behavior between China and America results of different idea of the classroom teaching. Through the comparison of two lessons, we can clearly know that the classroom teaching in America is student-centred, but is teacher-centred in China. So, in the American open philosophy lesson, the teacher constructs teaching situation through introducing a case and make the students to experience thinking collision in the case in order to trigger students to think about fair, equality, democracy and civil rights. However, in Chinese open philosophy lesson, the teacher introduced several cases to clarify philosophy idea without trigger students deeply speculate.

(2)Teaching objectives: Educational objectives of America aim at developing student's critical thinking and creative thinking. However, in real teaching process, the teacher only imparts so much knowledge to student without paying attention to developing student's creative thinking and the ability to resolve problem as well as cultivating student's learning ability.

(3)Teaching method: In America, discussion method is usually applied in classroom teaching. American educator John Dewey[8] thinks education is life and school is society. So, in American open philosophy lesson, the teacher constructs teaching situation through presenting several cases to students and made student's thinking collision through discussion and analyses the cases. At the same time, the teacher encourages student to speak out their thinking. It is benefit of inspire the minds of student and enhance student ability to analyze problem from multiple perspectives. It is benefit of developing student's language competence and ability to learn. However, in China, lecture way is usually applied in classroom teaching. Teaching process is treated as a special kind of cognitive process, namely gaining "indirect experience" process. So, university education in China focuses on imparting knowledge.

(4)Teaching evaluation: Main purpose of teaching evaluation is to provide information and feedback to teacher in order to improve the quality of teaching and learning. So, process 
evaluation is important. However, in China, summative evaluation is paid more attention. Students spend much more time to prepare terminal examination and neglect the process of learning and practice. Final test grade is limited in knowledge. Teacher neglects evaluate student's ability to resolve problem and students' participation in class. In American, teacher pays more attention to process of student learning and cultivating students' ability of resolving problem.

\section{Conclusions}

From analyzing and discussion to two cases above, it is revealed that there are a lot of differences of classroom teaching behavior in teaching idea, teaching method, teaching media and teaching evaluation between China and America. Particularly, in China, teacher pays attention to imparting complete knowledge system and to terminal examination. Teacher neglects cultivating innovative thinking and autonomous learning ability of student. In America, teacher pays attention to cultivating the students' interest and ability in independent exploration. It is emphasized to the initiative of students and the classroom interaction between teachers and students. The evaluation of learning process is important in the final evaluation. So, we should learn advanced teaching ideas from foreign, combined with China's actual situation, to improve the teaching in order to move from teacher-centered teaching to student-centered teaching.

\section{Acknowledgement}

This work is supported by Key Laboratory of Education Informatization for Nationalities (Yunnan Normal University), Ministry of Education, China. This work is also supported by the project of reform of teacher education in Yunnan Normal University (JSJY201414) and the project of education reform of graduate student in Yunnan Normal University(YJG2014-E02).

\section{References}

[1] Lin, J. Yifu, The Needham Puzzle: Why the Industrial Revolution Did Not Originate in China, Economic Development and Cultural Change. 43(1995) 269-292.

[2] M. Manenová, N. Žembová, Analysis of Lessons using Interactive Whiteboard focused on Pedagogical Interaction and Communication, Procedia - Social and Behavioral Sciences. 69(2012)1719-1728.

[3] N. A. Flanders, Analyzing Teaching Behavior, London: Addison-Wesley, 1970.

[4] P. Albergaria-Almeida, Classroom Questioning: Teachers' Perceptions and Practices, Procedia-Social and Behavioral Sciences. 2(2010) 305-309.

[5] R. E. Bartholomew, The effect of teaching methods on truancy, Electronic Journal of the American Association of Behavioral and Social Sciences, Retrieved from http://aabss.org/Perspectives2009/, December 2009.

[6] M. B. Rowe, Wait-time: Slowing down May Be A Way of Speeding up, Journal of Teacher Education. 37(1986) 43-50. 
[7] S. Muchemwa, Use of Nonverbal Communication in the Classroom as a Way of Enhancing Classroom Teaching: A Case Study of Solusi High School, Zimbabwe, Procedia-Social and Behavioral Sciences. 103(2013) 1279-1287.

[8] J. Dewey, Experience and Education, New York: Free Press, 1997. 